\title{
10 år med velfærdsteknologi: Strategi og praksis
} Af Jon Aaen, Jeppe Agger Nielsen og Kasper Trolle Elmholdt *)

\section{Resumé}

Velfærdsteknologidagsordenen indtager en væsentlig rolle i diskussion om det danske velfærdssamfund, navnlig på sundheds- og ældreområdet. Artiklen redegør for tendensen og ridser baggrunden op for den aktuelle interesse for velfærdsteknologi som teknologisk satsningsområde. Vi byder ind med en definition af paraplybegrebet velfærdsteknologi og viser, hvordan forhåbningerne til velfærdsteknologi afspejler fire sameksisterende perspektiver; et effektivitets-, empowerment-, medarbejder- og vækstperspektiv. Baseret på resultater fra telemedicinprojektet TeleCare Nord illustrerer vi, hvordan de fire velfærdsteknologiperspektiver udfolder sig i praksis, og vi diskuterer udfordringer forbundet med at realisere forhåbningerne til velfærdsteknologi.

\section{A. Introduktion}

Da begrebet velfærdsteknologi blev introduceret for godt 10 år siden, var det med forventninger om, at ny teknologi målrettet den offentlige velfærdsproduktion kunne imødekomme en række udfordringer i den offentlige sektor og samtidig være grobund for et nyt dansk industrieventyr. Selvom begrebet ikke knytter sig snævert til sundheds- og ældresektoren, er det navnligt på disse områder, at velfærdsteknologidagsordenen har vundet fodfæste som teknologisk satsningsområde (Nielsen, Andersen \& Sigh, 2016; Fredskild \& Dalkjær, 2017; Sorknaes et al., 2013; Danske Regioner et al., 2012).

*) Jon Aaen er ph.d.-studerende, Jeppe Agger Nielsen er professor mso, og Kasper Trolle Elmholdt er adjunkt - alle ved Institut for Statskundskab, Aalborg Universitet 
Her fremhæves teknologier som fx telemedicin, forflytningsteknologi, vasketoiletter, servicerobotter, virtual reality og wearables (med eksempelvis GPS eller sensorer til patientmonitorering) som en del af løsningen på ressourcemæssige og demografiske udfordringer med et stigende antal ældre og kronikere, som forventes at ramme Danmark og andre vestlige lande i de kommende år (Regeringen, KL, \& Danske Regioner, 2016; Östlund, Olander, Jonsson \& Frennert, 2015; Hofmann, 2013).

Mens velfærdsteknologi har vundet indpas i debatten om, hvordan velfærdssamfundet kan indrettes mest hensigtsmæssige (og smartest), er forståelserne af, hvad velfærdsteknologi indebærer, imidlertid mange. Det samme er kommunernes og sygehusenes erfaringer med at inddrage velfærdsteknologi i ydelser og services til borgerne. Efter 10 år med velfærdsteknologi, er ærindet i denne artikel, at gøre status over udviklingstendensen i et felt, hvori de teknologiske forudsætninger har udviklet sig drastisk. Kritiske perspektiver har (med rette) fremhævet, at begrebet velfærdsteknologi kan udgøre en "tom betegner" uden nogen essens og færdig defineret mening (Corneliussen \& Dyb, 2017: s. 168). I denne artikel er hensigten at komme nærmere essensen af velfærdsteknologi. Vi starter derfor med at definere velfærdsteknologi og vise, hvordan velfærdsteknologi adskiller sig fra andre teknologityper og -begreber. Dernæst illustrerer vi, hvordan forhåbningerne til velfærdsteknologi afspejler fire sammenhængende forestillinger om teknologiens potentialer; henholdsvis et effektivitets-, empowerments-, medarbejder- og vækstperspektiv. Endelig illustrerer vi gennem en case om telemedicin (Telecare Nord), hvordan de fire velfærdsteknologiperspektiver kommer til udtryk i praksis.

\section{B. Velfærdsteknologi: Hvad indebærer det?}

Undersøgelser af danskernes holdning til velfærdsteknologi tyder på, at de fleste er trygge ved, at der tages ny teknologi i brug i sundheds- og ældreplejen (Müller et al, 2012). I en undersøgelse gennemført af Digitaliseringsstyrelsen (2013) angiver 71 pct. af danskerne, at den offentlige sektor vil blive ligeså god eller bedre ved øget brug af velfærdsteknologi i fremtiden. 63 pct. af danskerne angiver, at de sandsynligvis selv gerne vil bruge velfærdsteknologi, hvis de får behov for pleje, og får det tilbudt som en mulighed (Dansk Erhverv, 2017). Hvad der ligger i det plastiske begreb velfærdsteknologi, og hvad respondenterne dermed har svaret på, kan dog dække over flere ting. Ofte afspejles begrebets plasticitet i meget brede definitioner. Fx defineres velfærdsteknologi i Den Danske Ordbog som ”viden og tekniske hjælpemidler, der bruges inden 
for fx ældre-, pleje- og sundhedsområdet” (Ordnet.dk, 2018). Andre definerer velfærdsteknologi som "teknologier, der øger livskvaliteten og/eller effektiviteten i samfundet" (Welfare Tech, 2018). Og i lovgrundlaget for den regeringsnedsatte 'Fonden for Velfærdsteknologi' fremgår det, at fonden skal fremme "velfærdsteknologiske løsninger, der øger produktiviteten i den offentlige service, reducerer ressourceforbruget, understøtter kvalitet og har fokus på at øge borgernes selvhjulpenhed" (BEK nr 832 af 18/06/2014). Med andre ord har vi at gøre med definitioner, der strækker sig fra at definere teknologi på bestemte felter (fx sundhedsområdet), til teknologi med bestemte egenskaber (livskvalitetsskabende) og endelig mod bestemte samfundsmæssige formål (ressourcemæssige besparelser).

Velfærdsteknologi omfatter samtidig en særdeles heterogen gruppe af teknologier, der kan anvendes til en lang række formål som fx rehabilitering, fjernbehandling og kommunikation, hverdagsaktiviteter, sygdomsovervågning eller social og emotionel stimulering. I Tabel 1 oplister vi en række eksempler på velfærdsteknologier på sundheds-, ældre-, børne- og ungeområdet. 


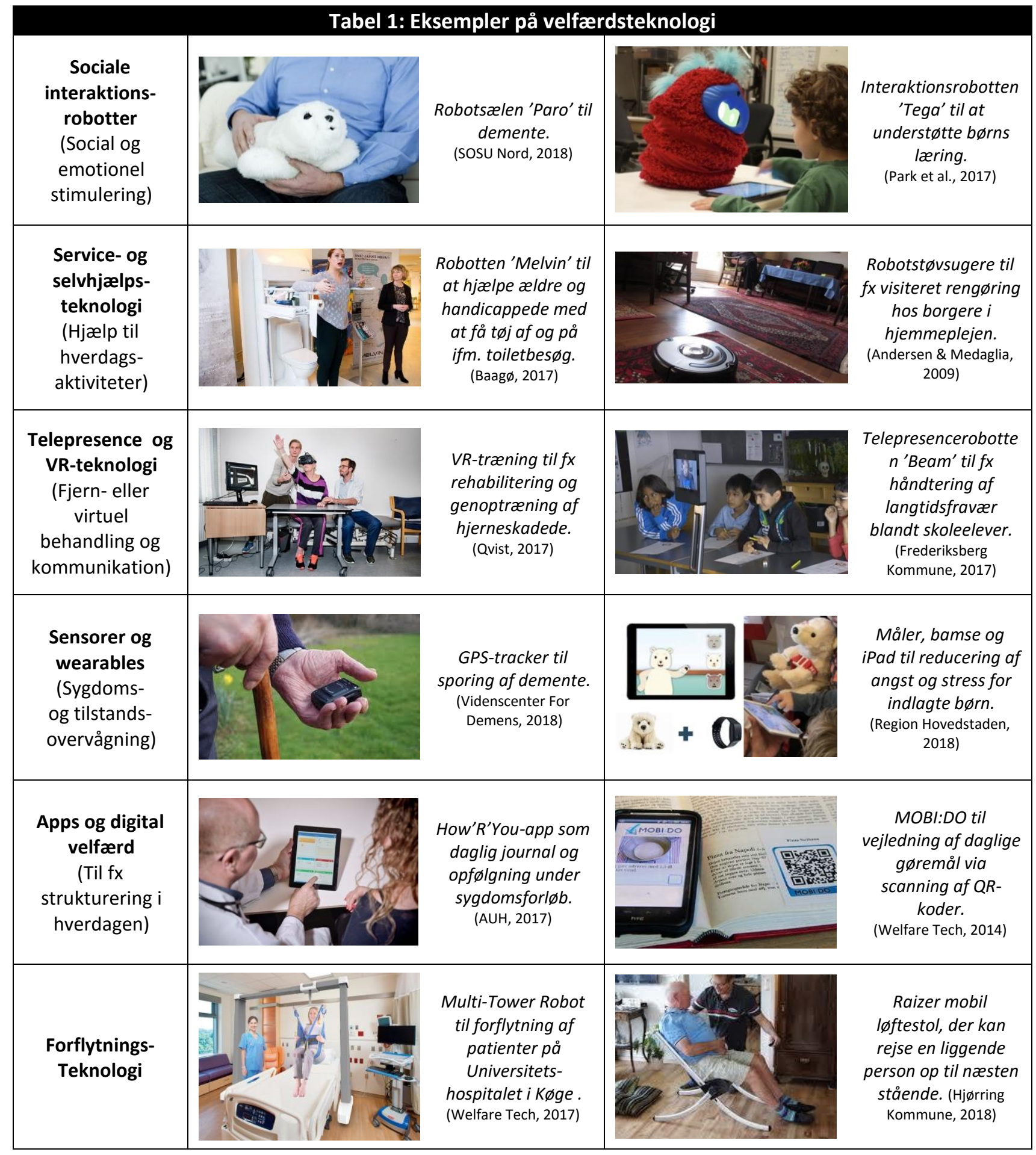


Fælles for de anførte velfærdsteknologier i Tabel 1 er, at de understøtter borgere ift. én eller flere velfærdsydelser. Sammenlignet med "back-office teknologier" - såsom IT-systemer til administration, dokumentation, styring og kontrol - synes et væsentligt karaktertræk ved velfærdsteknologi dermed at være, at der er tale om borgernere teknologier. Dette kendetegn medfører først og fremmest en teknologisk afgrænsning af et stadigt mere forskelligartet felt af teknologier.

Et andet karaktertræk ved velfærdsteknologi er, at teknologierne er tiltænkt at understøtte forebyggelse og selvhjulpenhed og/eller effektive og fleksible arbejdsgange i de borgervendte velfærdsydelser i den offentlige sektor som fx bevilliget ud fra Serviceloven. Disse karakteristika indebærer, at velfærdsteknologi afgrænser sig fra andre borgervendte teknologier som fx digitale selvbetjeningsservices, der mere knytter til begrebet e-government eller digital forvaltning. Endelig er udvikling og anvendelse af velfærdsteknologi (i de nordiske lande) ofte kendetegnet ved et tat organisatorisk samspil mellem private virksomheder (fx udviklere af teknologi), offentlige myndigheder (leverandør af velfærdsydelser) og borgere (brugere). Dette kendetegn afspejler den organisatoriske kompleksitet, som velfærdsteknologi er indlejret i. Opsummerende bliver vores bud på en definition derfor således: Velferdsteknologi er borgervendt teknologi, der understotter én eller flere velfardsydelser med henblik på at oge livskvaliteten for borgeren og/eller effektiviteten $i$ serviceleveringen, og som oftest udvikles og implementeres $i$ samspil mellem borgere (slutbrugere), frontmedarbejdere, offentlig administration og virksomheder.

\section{Hvor stammer begrebet velfærdsteknologi fra?}

En infomedia-søgning viser, at begrebet 'velfærdsteknologi' første gang optræder i september 2007 i nyhedsdækningen af Odense Kommunes deltagelse i EU-projekt PERSONA (Højland, 2007). Sidenhen har begrebet også bidt sig fast i Sverige og Norge under tilsvarende dagsordner (Dahlberg 2013; Corneliussen \& Dyb, 2017).

Den direkte oversættelse af 'velfærdsteknologi' til engelsk, 'Welfare Technology', er imidlertid ikke for alvor slået igennem uden for de nordiske lande. I stedet anvendes beslægtede, men ikke fuldt overlappende, betegnelser som Ambient Assisted Living, Assisted Living Technologies (ALT), Active and Assisted Living (AAL) eller det endnu bredere 'eHealth' - blandt andet båret frem af programmer hos hhv. EU og WHO. Betegnelsen 'eHealth' udsprang ved årtusindskiftet på 
linje med øvrige "e-betegnelser" som fx e-business, e-commerse og e-government af en ambition om at udnytte nye digitale muligheder til effektiviseringer og bedre service (Eysenbach, 2001). Her er tale om anvendelse af informationsteknologi i sundhedssektoren i bred forstand, som også inkluderer mere overordnede og strukturelle aspekter (Oh et al., 2005; WHO, 2016) end det borgerorienterede fokus, som er kendetegnende for anvendelsen af 'velfærdsteknologi'. Hvor 'telemedicin' er et eksempel på et overlappende teknologiområde, som indfanges i både eHealth-, AAL-, ALT- og velfærdsteknologilitteraturen, orienterer e-Health-litteraturen sig bredt mod anvendelsen af IT på sundhedsområdet. Litteraturen inkluderer i stadigt større omfang studier relateret til samspillet mellem teknologier, som falder uden for ovenstående definition af velfærdsteknologi (fx elektroniske patientjournaler og sundhedsdata) (Kierkegaard, 2013). Modsvarende orienterer ALT og AAL sig specifikt mod teknologier til "aktiv aldring" og personer med funktionsnedsættelse (Nugent, Coronato \& Bravo, 2013; Florez-Revuelta \& Chaaraoui, 2016; Greenhalgh et al., 2012; Sun et al., 2009; Ishiguro, 2018) - og har således mange lighedspunkter med velfærdsteknologibegrebet, men ikke med samme rummelighed ift. andre velfærdsområder, som inkluderes i velfærdsteknologibegrebet. Men selvom anvendelse af teknologi til at understøtte forskellige velfærdsydelser kan begribes forskelligt, er demografiske udfordringer, effektiviseringer, ønsket om øget selvhjulpenhed og jagten på nye kommercielle muligheder gennemgående tematikker, der præger både eHealth, ALT, AAL og velfærdsteknologibegreberne.

\section{Velfærdsteknologien som "firedobbelt win"}

Den aktuelle interesse for velfærdsteknologi bæres frem af en række offentlige og private aktører, internationalt (fx EU-Kommissionen, 2018), nationalt (fx Regeringen, 2013, 2017) og lokalt (fx Aarhus Kommune, 2018). Baseret på en gennemgang og analyse af en række strategidokumenter for udbredelse af velfærdsteknologi (herunder EU-Kommissionen, 2015, 2018; Regeringen, 2013, 2017; Regeringen, KL og Danske Regioner, 2016; Danske Regioner et al., 2012; KL, 2014, 2015, 2017) præsenterer vi i det følgende 'effektivitet', 'empowerment', 'medarbejder"'og vækst' som fire væsensforskellige, men også sameksisterende perspektiver på velfærdsteknologi. Eftersom de fire perspektiver udledes af en række strategidokumenter, skal de anskues som måder at retfærdiggøre og legitimere udbredelsen af velfærdsteknologi på, og de får på den måde også et positivt udtryk. ${ }^{1}$ 
I bestræbelserne på give en systematisk forståelse af de fire perspektivers forskelligheder sammenligner vi dem på tre dimensioner: teknologiens rolle, borger/bruger roller og fokus på værdiskabelse.

\section{Effektivitet: Velfærdsteknologi som arbejdskraftbesparende teknologi}

Velfærdsteknologi italesættes ofte ud fra et effektiviseringsrationale, hvor ny teknologi forventes at få den offentlige serviceproduktion til at "køre længere på literen” (se fx Regeringen, 2013, 2017). I 2014 angav ca. 75\% af kommunerne velfærdsteknologi som et af de væsentligste bidrag til effektiviseringsgevinster på både dagtilbud-, skole- og ældreområderne (KL, 2014). Teknologien tilskrives således en central rolle i opretholdelsen af det offentlige serviceniveau og som problemløser for demografiske og økonomiske udfordringer for den offentlige sektor. Heri fremstår et overvejende instrumentelt og effektivitetsorienteret syn på velfærdsteknologi, der ligger i forlængelse af en NPM-præget styringsforståelse (Greve \& Pedersen, 2017). Denne ”do more with less"-tankegang synes at tilgodese bestemte typer af velfærdsteknologier. Et eksempel herpå er KL's velfærdsteknologiske satsningsområder såsom forflytningsteknologi (hvor man med loftslifte går fra to til en medarbejder til løft af sengeliggende borgere), og de dertil udviklede værktøjer (Excel-regneark) til beregning og opstilling af business case og gevinstrealisering (KL, 2018). Et andet eksempel er snævre effektanalyser af fx robotstøvsugere, hvor sparet arbejdstid fremstår som den dominerende afhængige variabel (Andersen \& Medaglia, 2009). Lignende tematikker om 'nytteværdi' dukker hyppigt op i den internationale litteratur om Ambient Assisted Living teknologier (Heilesen, 2013). I et effektivitetsperspektiv er velfærdsteknologi dermed først og fremmest et økonomisk projekt, hvor borgeren tildeles en rolle som aftager af ressourcebesparende teknologi. Her knytter værdiskabelse sig til en økonomisk politik med effektivisering og økonomiske gevinster som afgørende argumenter for velfærdsteknologiens værdi.

\section{Empowerment: Velfærdsteknologi som frihedsteknologi}

”Der er både livskvalitet og god samfundsøkonomi i at udbrede digitale velfærdsløsninger, der giver frihed og gør den enkelte mere selvhjulpen” lyder det i den fællesoffentlige digitaliseringsstrategi 2016-2020 med henvisning til erfaringer med telemedicin, som måder at inddrage patienter i eget sygdomsforløb og give dem fleksibilitet og tryghed i hverdagen (Regeringen, KL og Danske Regioner, 2016:29). Effektiviseringsrationalet suppleres dermed med forventninger om mere kvalitative gevinster, hvori værdien af velfærdsteknologi kædes sammen 
med øget selvhjulpenhed, tryghed og værdighed for borgerne. Her er fokus på de sociale og "blødere" dimensioner af velfærdsteknologi, hvor teknologianvendelse antages at rykke ved magtog rollefordelingen mellem staten og borgerne/civilsamfundet ved at gøre "borgerne mere selvhjulpne, give bedre livskvalitet og mindske behovet for praktisk hjalp og personlig pleje” (Regeringen, 2013: 12). Med andre ord anses velfærdsteknologi som en mulighed for at redefinere relationen mellem borger og offentlig sektor, hvor borgeren forventes at indtage en mere aktiv rolle i den offentlige serviceproduktion (Clemensen \& Rasmussen, 2011). Dette kendetegn understreger det "empowerment"-potentiale, som knyttes til velfærdsteknologi, og understøtter en ny rolle, som går fra at være patienter til selvhjulpne og ligeværdige borgere (Wehner et al., 2013).

I dette perspektiv er det centrale succeskriterie, at borgene/patienterne oplever, at de bliver mere selvhjulpne og dermed får mulighed for at mestre deres funktionsnedsættelse. I Aarhus Kommune er arbejdet med velfærdsteknologi blevet til 'Center for Frihedsteknologi', der arbejder for at gøre borgerne mere selvhjulpne og forbedre arbejdsmiljøet - men som dog stadig også sigter mod at fremme effektivitet og økonomi for kommunen (Aarhus Kommune, 2018). I kontrast til effektivitetsperspektivet relateres værdi her primært til værdier som frihed og selvhjulpenhed.

\section{Velfærdsteknologi fra et medarbejderperspektiv}

En tredje forestilling relaterer sig til velfærdsteknologi som et middel til at løfte kvaliteten i frontlinjemedarbejdernes arbejde. Selvom der også peges på en række udfordringer i forhold til medarbejderes syn på velfærdsteknologi (Lassen, 2017) italesættes mange potentialer dog også. Eksempelvis fremhæves det, hvordan velfærdsteknologi kan bidrage til at mindske fysisk belastning, skabe arbejdsglæde og faglig udvikling (Regeringen, 2013; Kommunernes Landsforening, 2017). Velfærdsteknologi betragtes her som en ressource, der kan frisætte medarbejdere fra uhensigtsmæssige løft og muliggøre et fokus på de primære opgaver i den offentlige sektor, som beskrevet i den fælles offentlige strategi for digital velfærd:

Og når medarbejdere i den offentlige sektor ved hjælp af teknologi kan løse opgaverne nemmere og hurtigere, frigiver det tid og ressourcer til kernevelfærden (Regeringen, 2013: 4).

Der udtrykkes således forventning om, at velfærdsteknologi kan aflaste medarbejderen fra ikkeprimære opgaver, eksempelvis som KL (2017) beskriver, at brug af spiserobotter hos nogle 
borgere kan 'frigøre noget af medarbejdernes tid, som kan disponeres til andre opgaver, mens borgeren spiser' (s. 19). Udover at frigøre tid og skabe fleksibilitet i opgaveløsningen, fremhæves mulighederne for fysisk aflastning i form af 'bedre arbejdsstillinger' også (KL, 2017: 5).

Regeringen beskriver blandt andet forskellige løfteteknologier, der kan aflaste medarbejdere, og hvordan et vasketoilet eksempelvis kan gøre at 'medarbejderne i hjemmeplejen får færre opgaver i slidsomme stillinger' (Regeringen, 2013: 13). I tråd med ambitioner om mere borgerinddragelse og samskabelse generelt i den offentlige sektor fremhæves det også, at velfærdsteknologi gør, at medarbejdere og ledere skal have nye mere (superviserende) roller, hvor de i højere grad skal 'motivere og støtte den enkelte borger i at benytte og få værdi af de teknologiske løsninger' (Regeringen, 2013: 3). Velfærdsteknologi betragtes positivt set som et bidrag til faglig udvikling og en ny opgavevaretagelse. Inden for denne logik er det således den arbejdsmæssige værdi, som er i fokus.

\section{Vækst: Velfærdsteknologi som et industrieventyr}

Som et fjerde strategisk fokusområde italesættes velfærdsteknologi som en "god salgsvare" og et potentielt nyt industrieventyr, der gør offentlige og private organisationer i stand til at "køre nye veje” - ikke alene i form af nye servicemuligheder, men også i form af nye markeder og forretningsmuligheder (EU-Kommissionen, 2015). Her opfattes aldring ikke kun som en samfundsmæssig udfordring, men også som en stor vækstmulighed på nye markeder (Gustavsson, 2010; Nordic Centre for Welfare and Social Issues, 2010). Det ses både i internationale, nationale og lokale strategier. EU har igangsat en række initiativer til stimulering og udvikling af nye markeder, produkter og serviceydelser ifm. aktiv og selvhjulpen aldring (EU-Kommissionen, 2015). I den Fællesoffentlige Strategi for Digital Velfærd ønsker Regeringen, KL og Danske Regioner "(...) med fælles mål og konkrete initiativer bidrage til at give dansk erhvervsliv og forskning pejlemærker for de produkter og services, der efterspørges af den offentlige sektor i de kommende år” (Regeringen, 2013; side 3). Tilsvarende visioner videreføres i lokale kommunale strategier, hvor man eksempelvis blandt Aarhus Kommune finder ambitionen om ” at komme på verdenskortet ved at skabe et globalt forende udviklings- og erhvervsklima inden for området" (Aarhus Kommune, 2014). Det er således den kommercielle værdi, profilering og skabelse af arbejdspladser, som er i fokus i dette perspektiv.

Tabel 2 giver en oversigt over de fire perspektiver på velfærdsteknologi. 
Tabel 2: Fire dominerende velfærdsteknologiperspektiver

\begin{tabular}{|c|c|c|c|c|}
\hline & Effektivisering & Empowerment & Medarbejder & Vakst \\
\hline $\begin{array}{l}\text { Teknologiens } \\
\text { rolle }\end{array}$ & $\begin{array}{l}\text { Middel til } \\
\text { effektivitet, } \\
\text { fleksibilitet og } \\
\text { optimering af } \\
\text { arbejdsformer. }\end{array}$ & $\begin{array}{l}\text { Middel til større } \\
\text { livskvalitet og } \\
\text { en mulighed for } \\
\text { at redefinere } \\
\text { aktørernes } \\
\text { roller og } \\
\text { magtfordelingen } \\
\text { mellem dem. }\end{array}$ & $\begin{array}{l}\text { Fysisk } \\
\text { aflastning af } \\
\text { medarbejderen } \\
\text { og mulighed } \\
\text { for faglig } \\
\text { udvikling. }\end{array}$ & $\begin{array}{l}\text { Middel til } \\
\text { kommercielt } \\
\text { vækstpotentiale for } \\
\text { nye produkter og } \\
\text { services tilpasset et } \\
\text { nyt } \\
\text { forbrugermarked. }\end{array}$ \\
\hline Brugerens rolle & $\begin{array}{l}\text { Mindre } \\
\text { ressourcekrævende } \\
\text { modtagere af } \\
\text { velfærdsydelser }\end{array}$ & $\begin{array}{l}\text { Aktive og } \\
\text { selvhjulpne } \\
\text { borgere }\end{array}$ & $\begin{array}{l}\text { Aktive borgere } \\
\text { der skal } \\
\text { uddannes til at } \\
\text { bruge } \\
\text { teknologierne. }\end{array}$ & $\begin{array}{l}\text { Nye købekraftige } \\
\text { kundesegmenter }\end{array}$ \\
\hline $\begin{array}{l}\text { Fokus for } \\
\text { værdiskabelse }\end{array}$ & $\begin{array}{l}\text { Cost-benefit- } \\
\text { beregning af } \\
\text { nytteværdi/ } \\
\text { opstilling af } \\
\text { business cases }\end{array}$ & $\begin{array}{l}\text { Fokus på } \\
\text { hvordan } \\
\text { borgere og } \\
\text { medarbejdere } \\
\text { kan få glæde af } \\
\text { nye } \\
\text { teknologiske } \\
\text { muligheder }\end{array}$ & $\begin{array}{l}\text { Mindre } \\
\text { sygefravær, } \\
\text { større } \\
\text { arbejdsglæde } \\
\text { og bedre } \\
\text { kvalitet. }\end{array}$ & $\begin{array}{l}\text { Vækst og (private) } \\
\text { arbejdspladser }\end{array}$ \\
\hline
\end{tabular}

I det følgende vil vi illustrere, hvordan de fire perspektiver ser ud når de møder praksis.

\section{Velfærdsteknologi i praksis: Erfaringer med telemedicin}

Mens der er mange velfærdsteknologiske initiativer i Danmark, mangler der viden om, hvad de faktiske effekter af initiativerne er. Selvom det eksisterende vidensgrundlag er begrænset (og ofte alene indebærer evalueringer af pilotforsøg), er telemedicin et velfærdsteknologisk satsningsområde, hvor vi er i besiddelse af ganske god dokumentation for de hidtidige virkninger. 
Her kan især det nordjyske telemedicinske storskalaprojekt TeleCare Nord fremhæves. Projektet er særdeles veldokumenteret gennem en række forskningsprojekter og dertilhørende udgivelser om effekterne ved brugen af telemedicin til borgere med kronisk obstruktiv lungesygdom (KOL) (fx Hæsum, 2015; Lilholt, 2016; Udsen, 2016; Christensen, 2017). Sammenfattende bidrager afrapporteringerne fra TeleCare Nord-projektet med dybdegående viden og praksiserfaring vedrørende velfærdsteknologi som borgervendt teknologi, og dokumenterer i hvilken grad velfærdsteknologiske løsninger (her: telemedicin) kan forbedre borgernes livskvalitet, medarbejderne arbejdsvilkår samt de samfundsøkonomiske og vækstmæssige effekter herved.

\section{TeleCare Nord}

Telesundhed og telemedicin er blevet kaldt "en nøgle til fremtidens sundhedsydelser", og er fremhævet som et eksempel på velfærdsteknologi, der kan ”forny og effektivisere den offentlige service, behandling og pleje” (Regeringen, KL og Danske Regioner, 2012:3). Telemedicinske løsninger er en af de velfærdsteknologier, som har vundet indpas gennem en årrække, og som efterhånden har fået udbredelse på en række forskellige områder i såvel primær som sekundær sektor. På ’Det Telemedicinske Landkort' er der i skrivende stund 431 frivilligt indberettede, igangværende og afsluttede telemedicinske initiativer i Danmark. ${ }^{2}$ Heriblandt udmærker TeleCare Nord sig som et skelsættende projekt - også i et internationalt perspektiv - idet storskalaimplementering lykkedes i en kompleks interorganisatorisk samspil med forskellige og delvist modsatrettede interesser og dagsordner (Christensen, Nielsen, Gustafson \& Seemann, 2016; Christensen \& Nielsen, 2017).

Projektet udspringer af et pilotinitiativ (TELEKAT), der demonstrerede, hvordan telemedicin via øget kommunikation og bedre koordinering af forskellige aktiviteter pa tværs af aktører, organisationer og sektorer - kan give et bedre og mere sammenhængende patientforløb, reducere antallet af indlæggelser og ambulante kontroller, samt give øget tryghed og sygdomsmestring for patienterne (Seemann, Dinesen \& Gustafsson, 2014). På baggrund heraf gik Region Nordjylland, de 11 nordjyske kommuner, alment praktiserende læger og Aalborg Universitet sammen om at afprøve, om de lovende resultater kunne genskabes som storskalaprojekt målrettet borgere med KOL. Projektet forløb fra januar 2012 til juli 2015 og udgjorde et af fem nationale telemedicinske indsatsområder (Danske Regioner et al., 2012; TeleCare Nord, 2015).

Telemedicin handler grundlæggende om at bruge informations- og kommunikationsteknologi til at levere forebyggende, behandlende eller rehabiliterende sundhedsydelser over afstand. I 
TeleCare Nord-projektet betød det i praksis at udstyre KOL-patienter med en række teknologiske redskaber (TeleKit $\left.{ }^{3}\right)$, som gør dem i stand til at måle deres blodtryk, besvare på sundhedsrelaterede spørgsmål og indgå i dialog med sundhedsprofessionelle via beskedfunktion. Telekittet indsender de målte sundhedsdata til en database, som kan tilgås af patientens læge, sygehus og hjemmesygepleje i en open source-webapplikation (OpenTele). Den sundhedsprofessionelle kan derigennem diagnosticere, følge, behandle og rådgive om sygdomme over afstand. Både kommunale og regionale sundhedsmedarbejdere (hjemmesygepleje, sundhedscentre og sygehuse) samt læger i almen praksis kan tilgå til databasen, mens borgeren kan følge egne målinger via www.sundhed.dk. Da telekittet er mobilt, kan borgeren anvende udstyret overalt i Danmark med mobil bredbåndsdækning (TeleCare Nord, 2015). Den telemedicinske løsning rummer dermed både et dialogværktøj og et dataopsamlings- og monitoreringsværktøj.
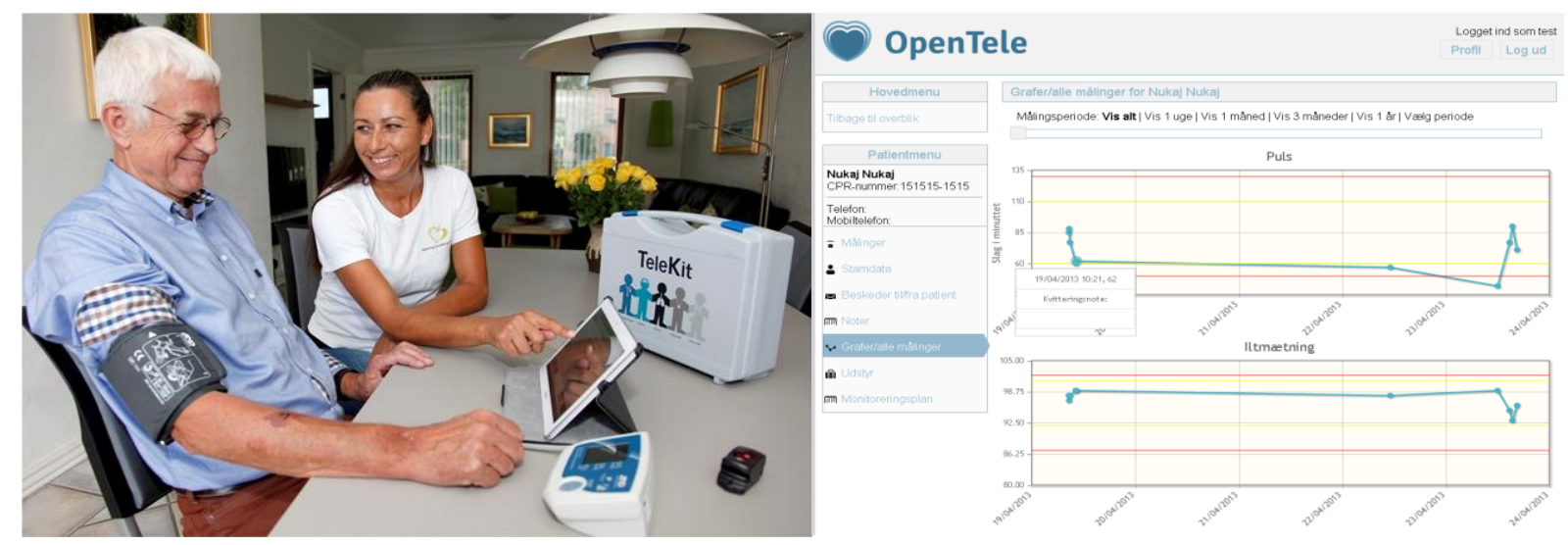

Figur 2: Det udleverede Telekit er illustreret på billedet (tv.) og visualisering af dataopsamling $i$ den tilknyttede app, OpenTele (th.).

\section{TeleCare Nord i et effektiviseringsperspektiv: De sundhedsøkonomiske gevinster er vanskelige at realisere}

KOL er en udbredt og omkostningstung sygdom, der i Danmark skønnes at udgøre 10\% af det samlede årlige sundhedsbudget for borgere ældre end 40 år (Udsen, 2016). Sygdommen er kronisk, men udviklingen kan ofte bremses med medicin, træning og livsstilsændringer såsom rygestop. Business casen for TeleCare Nord byggede således på en række forventninger til telemedicin-teknologien om sundhedsøkonomiske effekter for både region og kommuner, der kunne opnås ved brug af telemedicin som et middel til diagnostik, behandling, monitorering og pleje i storskala for KOL-patienter (TeleCare Nord, 2012; 2015). I primærsektoren kunne 
kommunerne forvente et mindre forbrug til pleje- omsorgsydelser, mens regionen i den sekundære sektor kunne forvente færre hospitalsindlæggelser og indlæggelsesdage. Dermed stod effektiviseringsperspektivet centralt i legitimeringen af TeleCare Nord i den oprindelige business case.

Den sundhedsøkonomiske evaluering af projektet viste imidlertid, at en generel anvendelse af telemedicin til alle patienter med KOL - på trods af en sundhedsmæssig gevinst målt i kvalitetsjusterede leveår - mod forventning var forbundet med merudgifter i størrelsesordenen kr. 5.400 pr. borger om året. Målrettes tilbuddet derimod kun til patienter med svær KOL, kunne man omvendt opnå en økonomisk besparelse i størrelsesordenen kr. 7.000 pr. borger om året primært som følge af færre indlæggelser (TeleCare Nord, 2015; Udsen, 2016). Med ca. 320.000 KOL-patienter i Danmark, hvoraf det anslås, at ca. 35.000 personer har svær KOL, ville en generel anvendelse af telemedicin dermed betyde en årlig merudgift på op mod 1,7 mia. kr., hvis telemedicin uddeles til alle KOL-patienter, mens en målrettet anvendelse ville kunne medføre en samlet årlig besparelse på op mod 245 mio. kr. (Stausholm \& Cichosz, 2017). Det skal naturligvis holdes for øje, at anvendelse af sådanne tal-estimater er behæftet med usikkerhed.

De sundhedsøkonomiske erfaringer fra TeleCare Nord har medført omfattende revurdering af de samfundsøkonomiske forventninger til telemedicin på nationalt plan. I den oprindelige business case for TeleCare Nord var der estimeret et årligt potentiale på 32. mio. kr. (72 årsværk) efter indfasning i Nordjylland - og ca. 320 mio. kr. (700 årsværk) på nationalt plan. I den reviderede business case fra 2015 var det årlige nationale potentiale derimod ændret til -5 mio. kr. (Pedersen, 2016; Danske Regioner et al., 2012; PA Consulting Group, 2015).

Ud fra et effektiviseringsperspektiv illustrerer erfaringerne fra TeleCare Nord udfordringerne ved den nuværende tilgang til sundhedsøkonomisk evaluering af velfærdsteknologier, idet de sundhedsøkonomiske effekter ved sådanne teknologier - sammenlignet med fx medicinindkøb - er mere komplekse at forudse, kvantificere og synliggøre (Udsen, 2016). Samtidig understreger resultaterne, at gevinstrealisering og værdiskabelse af velfærdsteknologi også afhænger af, hvordan teknologien målrettes de borgere, der har størst nytte af teknologien. Det fordrer samtidig en diskussion af, hvor og under hvilke forudsætninger velfærdsteknologi giver mest (sundhedsøkonomisk) mening. 


\section{Effekter for patienter: TeleCare Nord i et empowerment-perspektiv}

Projektbeskrivelserne af TeleCare Nord (2012, 2015) lægger stor vægt på at beskrive telemedicinteknologiens forventede og realiserede kvalitative patientnære effekter, herunder patient empowerment, der i projektet defineres som ”øget patienttryghed og tilfredshed, styrkede kompetencer til egenomsorg i eget hjem og en forstærket indflydelse på egen tilstand” (TeleCare Nord, 2012:4).

Lilholt et al. (2015) har i denne sammenhæng undersøgt brugeroplevelsen ved det udleverede Telekit, og hvordan det understøtter sygdomsmestring og patient empowerment. Her tilkendegav $88 \%$ af de adspurgte, at Telekit-systemet er let at bruge, mens $72 \%$ oplevede øget tryghed og $62 \%$ følte øget kontrol over egen sygdom ved brug af teknologien. Halvdelen af de adspurgte oplevede større opmærksomhed på deres KOL-symptomer, mens 16\% oplevede en større frihed i deres sygdomsforløb. Men hvor ovenstående brugerundersøgelse indikerer stor tilfredshed med den teknologiske løsning hos borgerne, er der dog ingen statistisk signifikant forbedring at spore i deres fysiske og psykiske sundhedsrelaterede livskvalitet, Health-Related Quality of Life (HRQoL), når der sammenlignes med traditionel KOL-behandling (Lilholt et al., 2017).

Empowermentperspektivet rummer endvidere et uddannelsesaspekt for borgeren ift. eksempelvis at kunne håndtere egen sygdom og være mere selvhjulpne. Her dækker begrebet 'Health Literacy' over "individets evne til at tilegne sig og anvende sundhedsrelateret information" (Hæsum, 2015:p.9).

Som en del af følgeforskningen i TeleCare Nord-projektet, har Hæsum (2015) undersøgt, hvorvidt et bestemt niveau af health literacy hos patienten er nødvendigt for få optimal gavn af den telemedicinske løsning, og om anvendelsen påvirker brugerens 'health literacy' over tid. Resultaterne for de kortsigtede effekter viste, at borgerne uagtet health literacy-niveau kunne anvende og få glæde af den telemedicinske løsning, hvilket understøtter karakteristikken af Telekit-løsningen som værende meget brugervenlig. Der blev dog ikke fundet langsigtede health literacy-effekter som følge af telemedicin-løsningen i et opfølgende studie, idet både telemedicingruppen (interventionsgruppen) og kontrolgruppen oplevede en tilsvarende stor stigning i health literacy-niveau på sigt (Hæsum, 2015). Resultaterne indikerer således, at den patientnære værdiskabelse beror på brugertilfredshed med teknologien og patienternes oplevede empowerment snarere end målbare effekter på sundhedsrelateret livskvalitet. 


\section{TeleCare Nord i et medarbejderperspektiv}

'Medarbejdertrivsel og arbejdsglæde' og 'nemmere rekruttering' var blandt de opstillede kvalitetsmål for TeleCare Nord og skulle sikres gennem en mere "veltilrettelagt hverdag med farre akutte patienter og nye behandlingstilbud" og "nye spandende arbejdsområder". Eksempelvis ville en række opgaver, der traditionelt varetages af lægen, fremover kunne varetages af sygeplejersker i det telemedicinske call-center (TeleCare Nord, 2012:7). Både slutevalueringen og Rambøll's eksterne evaluering melder om indledningsvise "implementeringsfrustrationer" hos særligt de lokale frontmedarbejdere (TeleCare Nord, 2015: Rambøll, 2015). Her har særligt de tværgående samarbejdsprocesser, tillidsopbygning og -vedligeholdelse samt interorganisatoriske konflikter præget medarbejdernes oplevelser med teknologien. Christensen (2017) argumenterer i den forbindelse for, at telemedicin på samme tid forstærker de eksisterende magtrelationer (mellem eksempelvis sygeplejersker og læger) og samtidig giver den svageste part i netværket nye muligheder for at lave modtræk og udjævne disse strukturer. I takt med erfaringer og gensidig tillid mellem aktørerne blev opbygget, modnedes det tværsektorielle samarbejde - og den generelle medarbejdertilfredshed med de telemedicinske ydelser blev øget (TeleCare Nord, 2015). Der findes ingen målinger af, hvorvidt rekrutteringsgrundlaget er blevet styrket som følge af projektet, men telemedicin er ved at blive indarbejdet i relevante sundhedsfaglige uddannelser på University College Nordjylland (UCN) (ibid.).

\section{Kommercielle effekter: TeleCare Nord i et vækstperspektiv}

Følgeforskningen tilknyttet TeleCare Nord omhandlede ikke de kommercielle effekter ved projektet, men en konsulentrapport af Hedevand, Winther \& Vangsgaard (2015) har - med støtte fra Region Nordjylland og Den Europæiske Socialfond - undersøgt små og mellemstore virksomheders (SMV'er) forretningsmuligheder inden for telemedicin med afsæt i TeleCare Nordprojektet. De peger på, at det tværsektorielle samarbejde samt fokus på effektiviseringer og patientforløbskoordinering i TeleCare Nord-projektet åbner op for en række kommercielle muligheder, fx udvikling og tilpasning af software til telemedicinske applikationer og udvikling og tilpasning af sensorsystemer til telemedicinske applikationer (Hedevand, Winther \& Vangsgaard, 2015:74).

Der er på den måde en række kommercielle muligheder, som brugen af velfærdsteknologi muligvis også kan være med til at understøtte. Det kommercielle potentiale kan udspecificeres i en bred værdikæde, der ikke alene omfatter udvikling af software og censorløsninger, produktion, 
distribution og installation af det tekniske udstyr, men også uddannelse og træning af brugere, serviceområder vedr. drift og vedligehold samt dataanalyse og sundhedsfaglige beslutningsstøttesystemer mm. (ibid.). Men selvom der eksempelvis forventes et globalt markedspotentiale for telemedicin, lader de kommercielle og vækstmæssige effekter endnu vente på sig. Det afspejles i den noget blandede succes hos de fire fremhævede virksomheder i Hedevand, Winther \& Vangsgaard-rapporten (2015), der ifølge CVR-registret i 2017 blot beskæftigede mellem 1-19 årsværk. .

På trods af (manglende) etablering af private arbejdspladser har TeleCare Nord-projektet i et vækstperspektiv dog demonstreret, at det på det velfærdsteknologiske område er muligt at udvikle et open-source-baseret offentlig-privat økosystem, der (på sigt) kan videreudvikles til kommercielle løsninger. Således er den nationale platform for telemedicin, OpenTele - som oprindeligt er udviklet i TeleCare Nord-projektet - i dag tilgængelig som open source hos Stiftelsen for Softwarebaserede SundhedsServices (4S) som et væsentligt element i telemedicinske infrastruktur og den landsdækkende udbredelse af telemedicinske løsninger (Christensen, Hansen, Kyng, \& Manikas, 2014).

\section{E. Afrunding}

Det overordnede mål i denne artikel har været at komme nærmere essensen af et af tidens buzzwords; velfærdsteknologi. Vi har redegjort for velfærdsteknologitendensen og defineret velfærdsteknologi som paraplybegreb dækkende over en mangfoldighed af borgervendte teknologier. Vi har analyseret italesættelsen af velfærdsteknologi som en ”firedobbelt-win”: Et effektivitetsperspektiv, hvori velfærdsteknologi ses som et middel til ressourceoptimering og håndtering af demografiske udfordringer. Et empowermentperspektiv, hvori velfærdsteknologi ses som et middel til større livskvalitet for borgere. Et medarbejderperspektiv, hvor velfærdsteknologi forventes at bidrage til større arbejdsglæde, lavere sygefravær og styrket fastholdelse og rekruttering af sundhedspersonale. Og et vækstperspektiv, hvori velfærdsteknologi ses som et nyt erhvervsmæssigt satsningsområde.

En gennemgang af de forsknings- og praksismæssige erfaringer fra det telemedicinske storskala projekt TeleCare Nord demonstrerer, hvordan alle fire perspektiver kan identificeres i bestræbelserne på at levere velfærdsydelser på nye måder. På den ene side peger vores analyse på, 
at velfærdsteknologi har en række umiddelbare og forenelige potentialer, hvor eksempelvis højere (oplevet) livskvalitet, øget selvhjulpenhed og sygdomsmestring hos borgeren kan føre til færre hospitalsindlæggelser og plejeomkostninger (hos specifikke patientgruppe). På den anden side lader disse potentialer sig ikke indfri så nemt - selv ikke efter storskalaimplementering er lykkedes. Her ses det, hvordan værdiskabelse og gevinstrealisering af velfærdsteknologi (ofte) udfordres af et kompleks inter-organisatorisk samspil, hvor forskellige professionelle fagligheder og normer skal integreres.

Endvidere viser forskellene i den oprindelige business case og den afsluttende evaluering af TeleCare Nord, hvordan teknologiens værdi løbende må diskuteres og revurderes - fra højstemte økonomiske og livskvalitetsforbedrende potentialer for alle KOL-patienter til mere afdæmpede effekter for specifikke patientgrupper. Der synes til stadighed at være ganske stor afstand mellem de optimistiske forventninger til velfærdsteknologi, som udtrykkes på konferencer og i strategidokumenter, til konkrete opnåede resultater i kommuner og på hospitaler (se også Nielsen, Mathiassen \& Newell, 2014). TeleCare Nord illustrerer derved den stadige udfordring mellem velfærdsteknologiens potentialer (retorik) og dennes aktualisering (praksis). Alligevel kan vi med den teknologiske udvikling og samfundsmæssige udfordringer in mente med stor sandsynlighed sige, at velfærdsteknologi vil fortsætte med at være et politisk og ledelsesmæssigt satsningsområde for den offentlige sektor i mange år frem. Vi har derfor brug for mere forskning, der belyser, hvordan disse teknologier forandrer måden, hvorpå forskellige velfærdservices leveres samt kvalificere de nuværende forståelser og forventninger til implementering og værdiskabelse.

\section{Noter}

${ }^{1}$ Til diskussionen om velfærdsteknologiens potentialer hører også mere kritiske perspektiver, hvor bekymringer omkring dehumanisering af borgerne/patienterne er fremtræedende. I denne sammenhæng tegnes med mellemrum et billede af de varme (omsorgsfulde) hænder vs. den kolde teknologi. Kritiske bidrag har blandt andet peget på, at en disharmoni mellem velfærdsteknologi (fx robotter og telemedicin) og de sundhedsprofessionelles etiske standarder overses, herunder nærhed til borgere/patienter. Som udtrykt af Heilesen (2017): "Teknologien kan have virkninger, som nogle vil opfatte som umyndiggørende, indgribende eller endda udfordrende for brugerens basale rettigheder og vardighed. Eksempelvis har nye og vardiladede ord som "robottvang" og "demensbamse" optrådt en del i medierne.” (s, 10). Der er imidlertid også perspektiver, som problematiserer en enten-eller 
skelnen, hvor teknologien nødvendigvis er kold og hænderne varme - kan et vaske-tørretoilet, for eksempel, ikke netop være en særdeles varm og myndiggørende teknologi? (Lassen, 2017; Mol et al., 2015).

${ }^{2}$ Det Telemedicinske Landkort vedligeholdes af MedCom og blev etableret af Regeringen, Danske Regioner og Kommunernes Landsforening som en del af den nationale handlingsplan for udbredelse af telemedicin fra august 2012. Se https://telemedicinsk-landkort.dk/

3 TeleKittet indeholder en tablet med SIM-kort til mobil bredbåndsdækning, en vægt og måler til blodtryk og iltindhold samt en tabletpen og brugervejledning.

${ }^{4}$ De omtalte virksomheder er Epital Health (2-4 ansatte), Medisat (opkøbt af TREFOR; nu 10-19 ansatte), Cure4You (2-4 ansatte) og Den lille Prins (enkeltmandsvirksomhed). 


\section{Referencer}

AAL-Programme (2015). Strategy 2014-2020 For The Active And Assisted Living Programme - A European platform for ICT-based solutions developed with SMEs and end-users to support older adults in everyday life. www.aal-europe.eu

Andersen, K.N \& Medaglia, R. (2009). Robotstøvsugning $i$ den offentlige sektor: Effekter og udfordringer. Center for Applied ICT - CAICT 2009(3). ISBN 978-87-92524-02-7

Clemensen \& Rasmussen (2011) Patient Empowerment and New Citizen Roles through Telehealth Technologies - The early stage. eTELEMED 2011: The Third International Conference on eHealth, Telemedicine, and Social Medicine, pp. 114-119. ISBN: 978-1-61208-119-9

Christensen, J. K. B. (2017). Network Dynamics in an Interorganizational Telemedicine Network: A longitudinal qualitative case study of the large-scale TeleCare North Program. Aalborg Universitetsforlag. Ph.d.-serien for Det Samfundsvidenskabelige Fakultet, Aalborg Universitet. DOI: 10.5278/vbn.phd.socsci.00065

Christensen, H.B., Hansen, K.M., Kyng, M., \& Manikas, K. (2014). Analysis and design of software ecosystem architectures - Towards the $4 \mathrm{~S}$ telemedicine ecosystem. Information and Software Technology 56, p. 1476-1492. https://doi.org/10.1016/j.infsof.2014.05.002

Christensen, J. K. B., \& Nielsen, J. A. (2017). Interorganisatorisk innovation i sundhedssektoren: Opskalering af et telemedicinsk pilotforsøg. Økonomistyring og Informatik, 32(4), 327-347.

Christensen, J.K.B., Nielsen, J.A., Gustafson, J., \& Seemann, J. (2016). Scaling up Telemedicine: Political Behavior in Innovation, Translation and Theorization. Paper presenteret ved Academy of Management Annual Meeting 2016, USA. https://doi.org/10.5465/ambpp.2016.17588abstract

Corneliussen, H. G, \& Dyb, K., (2017). Om teknologien som ikke fikk være teknologi - diskurser om velferdsteknologi. Immateriell kapital. Fjordantologien 2017, (eds.) John Roger Andersen, Eli Bjørhusdal, Jon Gunnar Nesse, Torbjørn Årethun Universitetsforlaget, s. 165-181.

Dahlberg, Å. (2013). Nyttokostnadsanalys vid införande av välfärdsteknologi - exemplet Posifon. Hjälpmedelsinstitutet

Dansk Erhverv (2017). Danskerne vil ha' velferdsteknologi. Dansk Erhvervs Perspektiv 2017 \# 5

Danske Regioner, Kommunernes Landsforening, Ministeriet for Sundhed og Forebyggelse, Social- og Integrationsministeriet, Erhvervs- og Vækstministeriet, Økonomi- og Indenrigsministeriet, Finansministeriet (2012). National handlingsplan for udbredelse af telemedicin. Fonden for Velfærdsteknologi, Juni 2012

Digitaliseringsstyrelsen (2013). Danskernes holdning til digital velferd - September 2013. København K. 
European Commission (2015). Growing the Silver Economy in Europe, Background Paper from the European Commission 23/02/2015.

European Commission (2018). What is the European Innovation Partnership on Active and Healthy Ageing (EIP on AHA)?. Accessed 29-01-2018. https://ec.europa.eu/eip/ageing/aboutthe-partnership_en

Eysenbach, G. (2001). What is e-health?. Journal of Medical Internet Research 3(2), e20.

https://doi.org/10.2196/jmir.3.2.e20

Florez-Revuelta, F. \& Chaaraoui, A.A. (2016). Active and Assisted Living: Technologies and Applications. ISBN: 9781849199872. https://doi.org/10.1049/PBHE006E ch22

Fredskild, T. U., \& Dalkjær, D. (2017). Velfærdsteknologi i sundhedsvæsnet (2. udgave). Gads Forlag. ISBN: 9788712053217

Greenhalgh, T., Procter, R., Wherton, J., Sugarhood, P., \& Shaw, S. (2012). The organising vision for telehealth and telecare: discourse analysis. BMJ open, 2(4), e001574.

https://doi.org/10.1136/bmjopen-2012-001574

Greve, C. \& Pedersen, A.R. (2017). Reform og forandring: Nye vilkår for ledelse og organisering, Gyldendal Public. ISBN-13:9788702226546

Gustavsson, L. (2010). Welcome From The AALA President, in Geyer, G., Nielsen, C.F., \& Zimmermann, K. (eds.) Active Ageing: Smart Solutions, New Markets Proceedings of the AAL FORUM 2010 Odense, pp. 25-27. ISBN 978-3-902580-08-5

Hedevand, Winther \& Vangsgaard (2015). TeleCare Nord Business Fra udvikling og afprovning til forretningsmuligheder for små og mellemstore virksomheder, Aalborg.

Heilesen, S.B. (2013) Om internationale forsknings- og udviklingsprojekter inden for velfardsteknologi. Rapport fra VIOL-projektet - Velfardsteknologi, Innovation, Omsorg og Laring. Roskilde Universitet.

Hofmann, B. (2013). Ethical Challenges with Welfare Technology: A Review of the Literature. Sci Eng Ethics 20013(19), pp. 389-406. DOI 10.1007/s 1 1948-011-9348-1

Højland, N (2007). Teknologi afløser menneskelig pleje. Jyllands-Posten, 13. september 2007, Sektion 2 (Erhverv og Økonomi), Side 6.

Hæsum, L. K. E. (2015). Health literacy and the use of telehomecare technology: - an exploration of both sides of the interaction. Aalborg Universitetsforlag. Ph.d.-serien for Det Sundhedsvidenskabelige Fakultet, Aalborg Universitet, DOI: 10.5278/vbn.phd.med.00014 Ishiguro, N. (2018). "Care robots in Japanese elderly care Cultural values in focus". In: Christensen, K., Pilling, D. (Ed.). The Routledge Handbook of Social Care Work Around the World (Chapter 18, pp. 256-270). London: Routledge. 
Kierkegaard, P. (2013). "eHealth in Denmark: A Case Study”. Journal of Medical Systems 37: 9991. https://doi-org.zorac.aub.aau.dk/10.1007/s10916-013-9991-y https://doi.org/10.1007/s10916013-9991-y

Kommunernes Landsforening, KL (2014). De effektive kommuner - Undersøgelse af kommunernes effektiviseringsarbejde 2013 og 2014. København

Kommunernes Landsforening, KL (2015). De effektive kommuner - Undersøgelse af kommunernes effektiviseringsarbejde 2014 og 2015. København

Kommunernes Landsforening, KL (2017). Slutmåling Det Fælleskommunale Program For Udbredelse Af Velfærdsteknologi 2014-2016. København

Kommunernes Landsforening, KL (2018). Business case model for forflytningsteknologi - fra 2 til 1. URL: http://www.kl.dk/Kommunale-opgaver/Centerforvelfaerdsteknologi/Varktojer-ogvejledninger-til-implementering-af-velfardsteknologi/Forflytningsteknologi---fra-2-til1/Business-case-model/ (Citeret 19-02-2018)

Lassen, A. M. (2017). Velfærdsteknologi i et medarbejderperspektiv - Et kvalitativt studie af kommunale medarbejderes erfaringer med velfærdsteknologi. Tidsskrift for omsorgsforskning 2(3).

Side: 106-1 17. https://doi.org/10.18261/issn.2387-5984-2017-02-08

Lilholt, P. H. (2016). Evaluation of a Telehealthcare Intervention for Patients with COPD: healthand patientrelated evaluation of the Danish telecare north trial. Aalborg Universitetsforlag. Ph.d.serien for Det Sundhedsvidenskabelige Fakultet, Aalborg Universitet, DOI:

10.5278/VBN.PHD.MED.00070

Lilholt, P. H., Hæsum, L. K. E., \& Hejlesen, O. (2015). Exploring user experience of a telehealth system for the Danish TeleCare North trial. In R. Cornet, L. Stoicu-Tivadar, A. Hörbst, C. L. P. Calderón, S. K. Andersen, \& M. Hercigonja-Szekeres (Eds.), Digital Healthcare Empowering Europeans: Proceedings of MIE2015, 27-29 May 2015, Madrid, Spain (pp. 301-305). IOS Press. Studies in Health Technology and Informatics, No. 210, DOI: 10.3233/978-1-61499-512-8-301

Lilholt P.H., Udsen F. W., Ehlers L., et al. (2017). Telehealthcare for patients suffering from chronic obstructive pulmonary disease: effects on health-related quality of life: results from the Danish ‘TeleCare North’ clusterrandomised trial. BMJ Open;7:e0 14587. doi:10.1136/ bmjopen2016-014587

Mol, A., Moser, I., \& Pols, J. (Eds.). (2015). Care in practice: On tinkering in clinics, homes and farms (Vol. 8). Verlag.

Müller C, Rasmussen S \& Forsberg L., (2012). Ældres erfaringer med velfærdsteknologi - En brugerundersøgelse udarbejdet for Ældre Sagen. København: Teknologisk Institut, april. 
Nielsen, J. A., Andersen, K. N., \& Sigh, A. (2016). Robots Conquering Local Government Services: A Case Study of Eldercare in Denmark. Information Polity, 2 1(2), 139-151.

https://doi.org/10.3233/IP-160381

Nielsen, J., Mathiassen, L., \& Newell, S. (2014). Theorization and translation in information technology institutionalization: Evidence from Danish home care. Mis Quarterly, 38(1): 165-186. https://doi.org/10.25300/MISQ/2014/38.1.08

Nordic Centre for Welfare and Social Issues (2010). Focus on Welfare Technology. ISBN: 978-877919-048-1

Nugent, Coronato \& Bravo (2013). "Preface”. In Nugent, Coronato \& Bravo, (Eds.). Ambient Assisted Living and Active Aging. 5th International Work-Conference, IWAAL 2013 Carrillo, Costa Rica, December 2013 Proceedings, pp. V-VI. ISSN 0302-9743

Oh, H., Rizo, C., Enkin, M., \& Jadad, A. (2005). What Is eHealth (3): A Systematic Review of Published Definitions. Journal of Medical Internet Research. 7 (1).

https://doi.org/10.2196/jmir.7.1.e1

Ordnet - Den Danske Ordbog (2018): ”Velfærdsteknologi”. URL: http://ordnet.dk/ddo/ordbog?query=velf\%C3\%A6rdsteknologi (Citeret 19-02-2018).

Östlund, B., Olander, E., Jonsson, O., \& Frennert, S. (2015). STS-inspired design to meet the challenges of modern aging. Welfare technology as a tool to promote user driven innovations or another way to keep older users hostage?. Technological Forecasting E Social Change 93, 82-90.

PA Consulting Group (2015). Business Case For National Udbredelse Af Telemedicinsk Hjemmemonitorering Til Borgere Med KOL.

Pedersen, K.M. (2016). Professor: Telemedicinske business cases er ren feberfantasi. Altinget, 1904-2016

Rambøll (2015). Ekstern evaluering af udvalgte fokuspunkter i Telecare Nord. September 2015 Regeringen, KL og Danske Regioner (2012). Telemedicin - En Nøgle Til Fremtidens Sundhedsydelser. National Handlingsplan For Udbredelse Af Telemedicin - Kort Fortalt. Regeringen (2013). ”Digital Velfærd En Lettere Hverdag - Fællesoffentlig Strategi For Digital Velfærd 2013-2020”. September 2013

Regeringen (2017). Sammenhængsreformen - Borgeren først - en mere sammenhængende offentlig sektor.

Regeringen, KL, \& Danske Regioner, (2016). "Et Stærkere Og Mere Trygt Digitalt Samfund Den fællesoffentlige digitaliseringsstrategi 2016-2020”. ISBN: 978-87-87353-88-5 
Seemann, J., Dinesen, B., \& Gustafsson, J. (2014). Interorganizational Innovation in Systemic Networks: TeleKat Findings. The Innovation Journal: The Public Sector Innovation Journal, 18(3), article 5, pp 1-9

Sorknaes A.D, Bech M, Madsen H, Titlestad I.L, Hounsgaard L, Hansen-Nord M, Jest P, Olesen F, Lauridsen J, Østergaard B. (2013) The effect of real-time teleconsultations between hospitalbased nurses and patients with severe COPD discharged after an exacerbation. Journal of Telemed Telecare, 19 (8): 466-474. https://doi.org/10.1177/1357633X13512067

Stausholm, M.N. \& Cichosz, S.L. (2017) Telemedicin til KOL-patienter: et tveægget sværd. Best Practice - Lungemedicin, Vol. 11, No. 6.

Sun, H., De Florio, V., Gui, N., \& Blondia, C. (2009, April). Promises and challenges of ambient assisted living systems. In Information Technology: New Generations, 2009. ITNG'09. Sixth International Conference on (pp. 1201-1207). Ieee. https://doi.org/10.1109/ITNG.2009.169

TeleCare Nord (2012). Business Case v.1.o februar 2012.

TeleCare Nord (2015). TeleCare Nord - Afslutningsrapport. Aalborg.

Udsen, F. W. (2016). Health Economic Evaluation of Telehealthcare: Can we include "why" and "under what circumstances" telehealthcare is cost-effective in health economic evaluation? .

Aalborg Universitetsforlag. Ph.d.-serien for Det Samfundsvidenskabelige Fakultet, Aalborg Universitet, DOI: 10.5278/VBN.PHD.SOCSCI.00064

Welfare Tech (2018). URL: https://www.welfaretech.dk/loesningsgalleri/om-velfaerdsteknologi (Citeret 19-02-2018).

Wehner et al. (2013). Empowerment Og Velfærdsteknologi Til Kronikere. Nordens Velferdscenter. ISBN: 978-87-7919-079-5

WHO (2016). Global difusion of eHealth: making universal health coverage achievable. Report of the third global survey on eHealth. ISBN 978-92-4-151178-0

Aarhus Kommune (2014). Visioner om velfærdsteknologi. URL: http://www.aarhus.dk/sitecore/content/Subsites/Velfaerdsteknologi/Home/Velfaerdsteknologi /Visioner-om-velfaerdsteknologi.aspx?sc_lang=da (Citeret 19-02-2018)

Aarhus Kommune (2018). Center for Frihedsteknologi. URL:

https://www.aarhus.dk/sitecore/content/Subsites/Velfaerdsteknologi/Home/Frihedsteknologi.a spx?sc_lang=da (Citeret 19-02-2018). 


\section{Tabel 1 - Referencer:}

AUH (2017). App hjælper børn med gigt og leukæmi. 02-03-17. URL:

http://www.auh.dk/presse/information-om-auh/nyheder/2017/app-hjalper-born-med-gigt-ogleukami/ (Citeret 19-02-2018)

Baagø, B. (2017). På toilet uden hjælp: Robot hjælper med af- og påklædning. JydskeVestkysten, 16-03-2017

Frederiksberg Kommune (2017). Yusuf modtager undervisning ved hjælp af robotten Beam. URL: http://www.svnp.dk/yusuf-modtager-undervisning-ved-hjaelp-robotten-beam/ (Citeret 19-O22018)

Hjørring Kommune, 2018. Raizer Løftestol. URL:

https://velfaerdsteknologi.hjoerring.dk/teknologier-og-projekter/raizer-loeftestol/ (Citeret 1902-2018)

Park, H.W., Rosenberg-Kima, R., Rosenberg, M., Gordon, G., \& Breazeal, C. (2017) Growing Growth Mindset with a Social Robot Peer. HRI '17, March 06-09, 2017, Vienna, Austria. DOI: http://dx.doi.org/10.1145/2909824.3020213

Qvist, 2017. Virtuelle ADL-øvelser skal hjælpe hjerne-skadede. URL:

http://www.etf.dk/ergoterapeuten/virtuelle-adl-oevelser-skal-hjaelpe-hjerne-skadede (Citeret 1902-2018)

Region Hovedstaden (2018). Et interaktivt følgedyr skal reducere angst og stress hos børn. 10-012018. URL: https://www.rigshospitalet.dk/boerneriget/nyheder-og-

presse/nyheder/Sider/2018/et-interaktivt-foelgedyr-skal-reducere-angst-og-stress-hosboern.aspx (Citeret 19-02-2018)

SOSU Nord 2018. Sælen Paro. URL: https://sosunord.dk/futurelab/robotteknologi/saelen-paro/ (Citeret 19-02-2018)

Videnscenter For Demens (2018). GPS-sporingsenhed til personer med demens. URL: http://www.videnscenterfordemens.dk/gps/ (Citeret 19-02-2018)

Welfare Tech (2014). Mobi:do lever videre i nyt firma. 27-11-2014. URL: https://www.welfaretech.dk/nyheder/2014/november/mobido-lever-videre-i-nyt-firma (Citeret 19-02-2018)

Welfare Tech (2017). Robotter skal forflytte patienter. URL: https://www.welfaretech.dk/nyheder/2017/februar/robotter-skal-forflytte-patienter (Citeret 1902-2018) 